\title{
Application of Zn-containing foliar fertilisers for recovery of the grain productivity potential of Zn-deficient maize plants
}

\author{
Krasimir Ivanov, ${ }^{1}$ Andon Vassilev, ${ }^{2}$ Anyo Mitkov, ${ }^{3}$ Nguyen Nguyen, ${ }^{1}$ Tonyo Tonev ${ }^{3}$ \\ ${ }^{1}$ Department of Chemistry; ${ }^{2}$ Department of Physiology and Biochemistry; ${ }^{3}$ Department of Farming and \\ Herbology, Agricultural University of Plovdiv, Plovdiv, Bulgaria
}

\section{Highlights}

- The application of foliar fertilisers is extremely suitable as the possibility of much faster zinc absorption than from the soil.

- Zn-fertilisation of maize plants during the initial growth stages plays a decisive role in the formation of the reproductive organs of maize.

- Foliar zinc fertilisers can entirely recover the physiological performance of plants grown under conditions of zinc deficiency.

\begin{abstract}
Maize is one of the most sensitive industrial crops of zinc supply. Questions about fertilisation methods and the type of fertilisers used are the subject of serious scientific discussion. The key objective of this paper was to evaluate the possibilities to recover the yielding potential of $\mathrm{Zn}$-deficient young maize plants by application of nanosized $\mathrm{Zn}$-containing foliar fertilisers.

The agronomic response of $\mathrm{Zn}$-deficient maize plants to foliar fertilisation with nanoscale zinc-containing foliar fertilisers was investigated. The study was conducted in two stages: i) planting and growing the plants under controlled conditions in a zinc-deficient environment for three months; and ii) moving the plants and continuing the experiment in field conditions. A single spray with two nanosized zinc-containing foliar fertilisers was carried out. The physiological status of the plants and the dynamic of zinc and micro- and macroelements concentration in plant organs were
\end{abstract}

Correspondence: Krasimir Ivanov, Department of Chemistry, Agricultural University of Plovdiv, 12 Mendeleev St., 4000 Plovdiv, Bulgaria. E-mail: kivanov1@abv.bg

Key words: Maize; foliar fertiliser; zinc hydroxy nitrate; mineral content; photosynthesis; grain productivity.

Acknowledgements: this work was partially supported by the Bulgarian Ministry of Education and Science under the National Research Programme Healthy Foods for a Strong Bio-Economy and Quality of Life approved by DCM No. 577/17.08.2018.

Received for publication: 27 October 2020.

Revision received: 31 January 2021.

Accepted for publication: 5 February 2021.

(C) Copyright: the Author(s), 2021

Licensee PAGEPress, Italy

Italian Journal of Agronomy 2021; 16:1759

doi:10.4081/ija.2021.1759

This article is distributed under the terms of the Creative Commons Attribution Noncommercial License (by-nc 4.0) which permits any noncommercial use, distribution, and reproduction in any medium, provided the original author(s) and source are credited. monitored. The influence of foliar zinc fertilisation on yield and grain structural components has been determined. Our results indicated that zinc fertilisation throughout the initial growth stages plays a decisive role in the formation of the reproductive organs of maize plants. Foliar zinc fertilisers can entirely recover the physiological performance of plants grown under conditions of zinc deficiency.

\section{Introduction}

Zinc is an essential plant micronutrient taking part in many physiological processes in plants. More than 300 enzymes need zinc as a metallic cofactor, including carbonic anhydrase, superoxide dismutase, alcohol dehydrogenase, and many others (Broadley, 2012; Hafeez et al., 2013). However, lack of plant available $\mathrm{Zn}$ forms appears in many alkaline soils, soils with high phosphorus levels, sandy low organic matter soils, as well as a result of wet and cold weather during early growing season (Camberato and Maloney, 2012; Broadley et al., 2007).

Maize is known as a crop more sensitive to zinc supply as compared to other micronutrients and other crops (Alloway, 2009; Liu et al., 2016; Subbaiah et al., 2016). It is accepted (Rehm et al., 1983; Mills, 1996) that the sufficient tissue levels of zinc in maize are between 20 and $60 \mathrm{mg} \mathrm{kg}^{-1}$. Its deficiency is distinguished by interveinal chlorosis and/or white mid-leaf streaking (Drissi et al., 2015) and can result in reduce yield (Alloway, 2009; Cakmak, 2009). Deficiencies in zinc and other mineral elements in plants can be due to many factors detailed in the literature (Sadeghzadeh, 2013). Usually, the correction of this deficiency is achieved by soil fertilisation. Very often for various reasons such as high carbonate content in the soil, high $\mathrm{pH}$, insufficient organic matter content and other soil minerals are not efficiently taken up by plants. In these cases, the foliar fertilisation can lead to better results ( $\mathrm{Li}$ et $a l ., 2016)$. In the case of zinc deficiency, water-soluble zinc salts or zinc oxide are most commonly used (Cakmak, 2009; Tahir et al., 2009; Fernandez and Brown, 2013). A disadvantage of $\mathrm{ZnO}$ is its low solubility in water $\left(3.0 \mathrm{mg} \mathrm{L}^{-1}\right)$, which prevents its effective absorption by plants, as well as the uneven distribution of the suspension on the leaf surface (Fageria et al., 2009; Singh et al., 2013). A common problem with soluble inorganic species is the risk of phytotoxicity (Golden et al., 2016) reported foliar injury symptoms after application of Zn-ethylenediaminetetraacetic acid (EDTA), zinc-citrate and $\mathrm{ZnSO}_{4}$ as foliar fertilisers to corn, expressed in grey/brown flecking, localized chlorosis and necro- 
sis. (Drissi et al., 2015) observed brown areas on corn leaves, emerged after foliar application of $\mathrm{ZnSO}_{4} \cdot 7 \mathrm{H}_{2} \mathrm{O}$, which is similar to symptoms reported by Mississippi corn producers.

The disadvantages of highly soluble inorganic salts can be overcome by the use of foliar nanoscale fertilisers with particles size smaller than $100 \mathrm{~nm}$. One of the most popular commercial products (Zintrac 700) with a zinc content of $700 \mathrm{~g} \mathrm{~L}^{-1}$ and crystal size from $50-70 \mathrm{~nm}$ was also used in our study. It is known that maize plants need the maximum amount of zinc at precisely certain stages of their development in a relatively short time (Potarzycki, 2010). A little soluble $\mathrm{ZnO}$ may not always fully meet these needs (Ivanov et al., 2019). As an alternative to the zinc oxide that can be used are complex zinc salts with a better solubility than $\mathrm{ZnO}$ and significantly less solubility than inorganic zinc salts. They can protect plants from phytotoxicity and provide a sufficient amount of zinc for healthy plant growth. Zinc hydroxy nitrate $(\mathrm{ZnHN})$ with composition $\mathrm{Zn}_{5}(\mathrm{OH})_{8}\left(\mathrm{NO}_{3}\right)_{2} \cdot 2 \mathrm{H}_{2} \mathrm{O}$ is announced as the most suitable long-lasting foliar fertiliser (Li et al., 2012, 2014). It can be obtained in the form of plates (Li et al., 2012; Ivanov et al., 2017) with dimensions between 500 and $1800 \mathrm{~nm}$ width and length, less than $100 \mathrm{~nm}$ thickness and solubility in water $37.16 \mathrm{mg} \mathrm{L}^{-1}$. This shape of the crystals allows them to be retained on the surface of the leaves and act as a long-lasting foliar fertiliser, allowing the plants to be supplied with the required amount of zinc without risk of phytotoxicity. Diagnostic tools are important to decide which foliar zinc fertilisers and at what rate should be applied to maize crop. The achieved zinc concentration in plant organs after fertiliser application could be a candidate for its effectiveness. However, Fernandez and Brown (2013) pointed out that even though the micronutrient concentration in the plant tissue has increased, physiological micronutrient utilization may not occur due to its possible adsorption in the apoplast space. A combination of mineral analysis with physiological measures (gas exchange, chlorophyll determination, chlorophyll fluorescence) is the best approach for checking both zinc deficiency (Wang and Jin, 2005; Mattiello et al., 2015) as well as zinc fertiliser effectiveness (Liu et al., 2020). The key objective of this paper is to evaluate the possibilities to recover the yielding potential of $\mathrm{Zn}$-deficient young maize plants by application of nanosized $\mathrm{Zn}$-containing foliar fertilisers. The sensitivity of maize to zinc fertilisation and its effect on the physiological status of the plants are investigated also.

\section{Materials and methods}

\section{Materials}

Bulgarian maize hybrid Kneja 300 was used in our experiment. Preliminary analysis of corn grains (4433 grains kg-1) showed zinc content $14.81 \mathrm{mg} \mathrm{kg}^{-1}$. Commercial foliar fertiliser (YaraVita ${ }^{\mathrm{TM}}$ ZINTRAC ${ }^{\text {TM }} 700$, delivered by KVS Agro Bulgaria), containing nanosized $\mathrm{ZnO}$ and synthesised by us nanosized zinc hydroxy nitrate suspension was used as foliar fertilisers.

\section{Methods}

\section{Synthesis of zinc hydroxide nitrate}

The preparation of zinc hydroxide nitrate $(\mathrm{ZnHN})$ with content $\mathrm{Zn}_{5}(\mathrm{OH})_{8}\left(\mathrm{NO}_{3}\right)_{2} \cdot 2 \mathrm{H}_{2} \mathrm{O}$ was performed by pouring $\mathrm{NaOH}(3.2 \mathrm{M}$ solution) into $\mathrm{Zn}\left(\mathrm{NO}_{3}\right)_{2} \cdot 6 \mathrm{H}_{2} \mathrm{O}$ (3.2 M solution) under vigorous stirring at $60^{\circ} \mathrm{C}$ (Ivanov et al., 2017). The initial $\mathrm{OH} / \mathrm{Zn}$ molar ratio was 1.6 and the time of precipitation was 30 minutes. The white precipitate was characterized by thermal analysis (TG, DTG and DTA), X-ray diffraction, scanning electron microscopy (SEM),
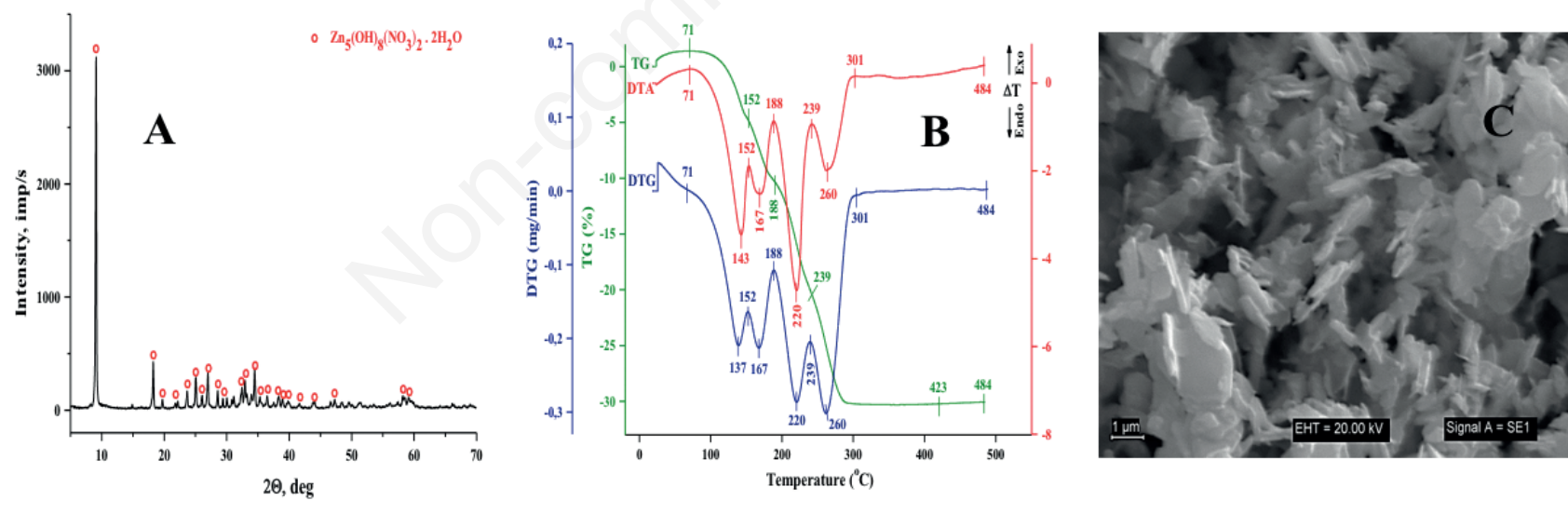

Figure 1. X-ray pattern (A), DTA, DTG and TG curve (B), and SEM image (C) of a typical sample of ZnHN.

Table 1. Nutrient solution composition.

\begin{tabular}{llll} 
Macroelements & \multicolumn{2}{l}{ Nicroelements } \\
$\mathrm{Ca}$ & $\mathrm{Ca}\left(\mathrm{NO}_{3}\right)_{2}, 1.000 \mathrm{~g} \mathrm{~L}^{-1}$ & $\mathrm{Zn}$ & $\mathrm{ZnSO} .7 \mathrm{H}_{2} \mathrm{O}, 0.576 \mathrm{mg} \mathrm{L}$ \\
$\mathrm{P}$ & $\mathrm{KH}_{2} \mathrm{PO}_{4}, 0.25 \mathrm{~g} \mathrm{~L}^{-1}$ & $\mathrm{Cl}$ & $\mathrm{KCl}, 3.728 \mathrm{mg} \mathrm{L}^{-1}$ \\
\hline $\mathrm{Mg}$ & $\mathrm{MgSO}_{4} .7 \mathrm{H}_{2} \mathrm{O}, 0.25 \mathrm{~g} \mathrm{~L}^{-1}$ & $\mathrm{~B}$ & $\mathrm{H}_{3} \mathrm{BO}_{4}, 1.546 \mathrm{mg} \mathrm{L}^{-1}$ \\
$\mathrm{~K}$ & $\mathrm{KCl}, 0.125 \mathrm{~g} \mathrm{~L}^{-1}$ & $\mathrm{Mn}$ & $\mathrm{MnSO}_{4}, 0.338 \mathrm{mg} \mathrm{L}^{-1}$ \\
\hline $\mathrm{Fe}_{1}$ & $\mathrm{FeCl}_{3}, 0.012 \mathrm{~g} \mathrm{~L}^{-1}$ & $\mathrm{Cu}$ & $\mathrm{CuSO}_{4}, 0.124 \mathrm{mg} \mathrm{L}^{-1}$ \\
$\mathrm{Fe}_{2}$ & $\mathrm{FeEDDHA}, 0.01 \mathrm{~g} \mathrm{~L}^{-1}$ & $\mathrm{Mo}$ & $\mathrm{Na}_{2} \mathrm{MoO}_{4}, 0.122{\mathrm{mg} . \mathrm{L}^{-1}}$ \\
\hline
\end{tabular}


transition electron microscopy (TEM), and inductively coupled plasma (ICP) spectrometry. The preparation of nanosized $\mathrm{Zn}_{5}(\mathrm{OH})_{8}\left(\mathrm{NO}_{3}\right)_{2} \cdot 2 \mathrm{H}_{2} \mathrm{O}$ with sheet-like form and thickness in the range $50-80 \mathrm{~nm}$ is illustrated in Figure 1. Thermal analysis shows a weight loss of $33.12 \%$, which is very close to the theoretical one $(34.67 \%)$. In the XRD pattern, only typical zinc hydroxy nitrate lines can be seen.

\section{Controlled experiment}

A controlled experiment was carried out in a climatic chamber of the department of Physiology, the Agricultural University of Plovdiv in 2019 from early March to late May. The plants were grown as a substrate-hydroponic culture on $1 / 2$ strength Hoagland nutrient solution (Table 1) which was replaced weekly to maintain nutrient concentrations at desired levels.

The maize plants were cultivated in a controlled environment: photoperiod - 12 hours, photosynthetic photon flux density (PPFD) $-200 \mu \mathrm{mol} \mathrm{m} \mathrm{s}^{-1}$ (cool-white fluorescent lamps), temperature $25 \pm 1{ }^{\circ} \mathrm{C} / 20 \pm 1^{\circ} \mathrm{C}$ (day/night) and relative air humidity - $60 \pm 5 \%$. After the emergence, the plants (36 pieces) were divided into four groups of nine plants (three repetitions, each repetition with three plants) - control (Variant I) and Zn-deficient groups (Variants IIIV). The control group was fed with a complete (all nutrients) solution, while the other by the same solution but without $\mathrm{Zn}$. Single spraying in mid-April (4-5 fully emerged leaf) was performed as follows: i) Variant III-spraying Zn-deficient plants with $25 \mathrm{~mL}$ commercial foliar fertiliser, containing nanosized $\mathrm{ZnO}$ of $4.36 \mathrm{~g}$ $\mathrm{L}^{-1}$ (3.5 $\mathrm{g} \mathrm{Zn} \mathrm{L}^{-1}$ ); and ii) Variant IV - spraying Zn-deficient plants with $25 \mathrm{ml}$ nanosized zinc hydroxy nitrate, synthesized by us with $\mathrm{Zn}$ concentrations of $3.5 \mathrm{~g} \mathrm{~L}^{-1}$. The effects of the applied fertilisers on $\mathrm{Zn}$-deficient plants were evaluated two weeks after the foliar feeding using as criteria leaf gas exchange and chlorophyll fluores- cence parameters, macro- and microelement content of plant organs as well as fresh biomass of the plants.

At the end of May, three plants of each variant were removed from the chamber (Figure 2) and carefully washed to remove zinc from the surface. Fresh biomass as well as macro- and microelement content in plant organs were measured.

\section{Field experiment}

The remaining plants after the controlled experiment ( 6 plants of each variant) were moved to the University Experimental Research Farm. The soil in this area was alluvial with an alkaline $\mathrm{pH}(7.88)$ and low content of organic matter $(1.60 \%)$. It is characterised by a low content of available Fe $\left(7.40 \mathrm{mg} \mathrm{kg}^{-1}\right)$, medium content of available $\mathrm{N}\left(41.45 \mathrm{mg} \mathrm{kg}^{-1}\right), \mathrm{P}\left(41.86 \mathrm{mg} \mathrm{kg}^{-1}\right), \mathrm{K}$ (202,70 mg kg-1) and $\mathrm{Mn}\left(13.62 \mathrm{mg} \mathrm{kg}^{-1}\right)$ and high content of $\mathrm{Cu}$ (2.24 mg kg${ }^{-1}$ ) compared to the average content of these elements in Bulgarian soils. The content of available $\mathrm{Zn}$ was $3.35 \mathrm{mg} \mathrm{kg}^{-1}$ and can be classified as a medium according to the MAAF 1998 classification (Papadopoulos et al., 2009).

After harvesting (end of September), the cobs were collected and random samples of grain were mixed, milled and analysed for dry matter, protein, fat and starch. The roots, stems and leaves of the plants were analysed for micro- and macronutrient content.

\section{Chemical and physiological analysis}

Random samples of roots, stems and leaves were dried, mixed, milled and analysed for zinc, micro and macroelements in three replications. The samples were digested by MARS 6 - Microwave Digestion System - CEM Corporation, using a mixture of $\mathrm{HNO}_{3}$ and $\mathrm{H}_{2} \mathrm{O}_{2}$, and a quantitative determination was performed by ICP Spectrometer "Prodigy 7". The results are expressed on a dry matter (DM) basis. The cobs kernel were air-dried and analysed for dry matter, protein, fat and starch in the University laboratory, accred-

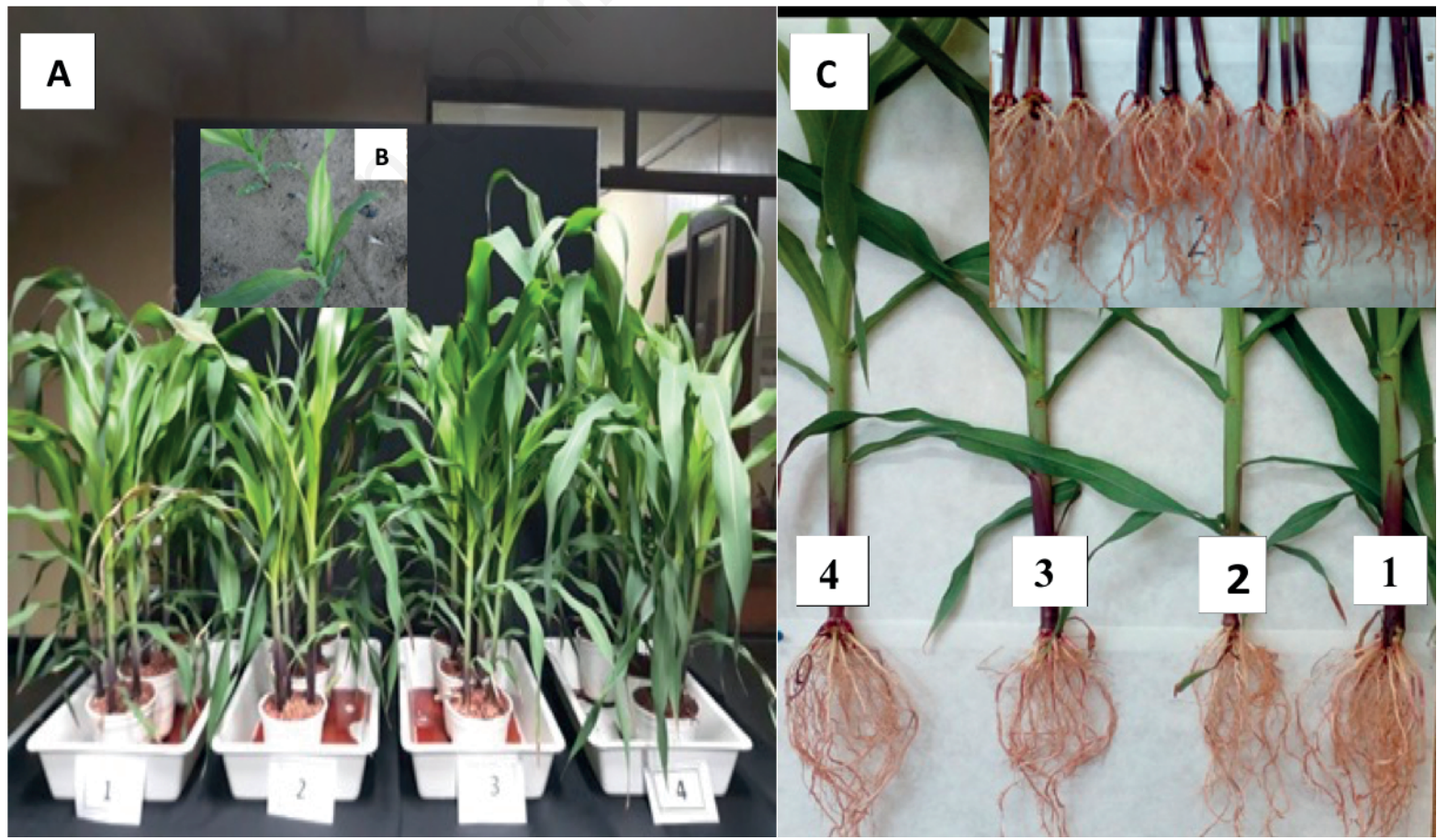

Figure 2. Controlled experiment: A) maize plants two weeks after spraying; B) maize plants two weeks before spraying; C) maize plants at the time of moving to experimental farm. 
ited under BDS EN ISO 17025/2006 for soil and plant analyses.

Leaf gas exchange (A, net photosynthetic rate; E, transpiration rate; $g_{s}$, stomatal conductance) was measured by an open photosynthetic system LCpro+ (ADC, England). Before the measurements, plants from all treatments were adapted for 1 hour at PPFD of $450 \mu \mathrm{mol} \mathrm{m} \mathrm{m}^{-2} \mathrm{~s}^{-1}$ and temperature $25^{\circ} \mathrm{C}$ and thereafter measured at the same conditions.

The selected chlorophyll fluorescence parameters were measured with a pulse modulation fluorometer (MINI-PAM, Heinz Walz, Germany). After dark adaptation $(30 \mathrm{~min})$ the minimal $\left(\mathrm{F}_{0}\right)$ and the maximal level of fluorescence $\left(\mathrm{F}_{\mathrm{m}}\right)$ were measured and the maximal quantum yield of PSII $\left(\mathrm{F}_{\mathrm{v}} / \mathrm{F}_{\mathrm{m}}\right)$, was calculated as $\mathrm{F}_{\mathrm{v}}=\mathrm{F}_{\mathrm{m}}$ $-\mathrm{F}_{0}$. After light adaptation (30 $\mathrm{min}$ ) the apparent electron transport rate $(\mathrm{ETR})$ was determined $\left[\mathrm{ETR}=\mathrm{Y} * \mathrm{PAR}^{*} 0.5 * 0.84\right.$, where $\left.\left.\mathrm{Y}=\left(\mathrm{F}_{\mathrm{m}}{ }^{\prime}-\mathrm{F}\right) / \mathrm{F}_{\mathrm{m}}{ }^{\prime}\right)\right]$, as well as the photochemical $\left(\mathrm{qP}=\left(\mathrm{F}_{\mathrm{m}}{ }^{\prime}-\right.\right.$ $\mathrm{F}) /\left(\mathrm{F}_{\mathrm{m}}{ }^{\prime}-\mathrm{F}_{0}\right)$ and the non-photochemical quenching $\left(\mathrm{qN}=\left(\mathrm{F}_{\mathrm{m}}-\right.\right.$ $\left.\mathrm{F}_{\mathrm{m}}{ }^{\prime}\right) /\left(\mathrm{F}_{\mathrm{m}}-\mathrm{F}_{0}\right)$, where $\mathrm{qP}$ and $\mathrm{qN}$ were calculated according to Schreiber (2004). The total chlorophyll content was determined using CCM-300 (ADC BioScientific Ltd.).

Statistical analysis was performed using one-way ANOVA (for $\mathrm{P}<0.05$ ). Based on ANOVA results, a Tukey's test for the main comparison at a $95 \%$ confidence level was applied.

\section{Results and discussions}

Impact of foliar fertilisation on plant growth and physiology

It is generally accepted that the characteristic symptoms of zinc deficiency include chlorosis on young leaves, thin stems and reduced leaf size (Marschner, 2011). Our results are consistent with this understanding. In our experiment conducted in the climatic chamber, we found such symptoms, albeit relatively weak being expressed. The average amount of fresh mass of the plants varies within a relatively narrow range - 48.1, 42.0, 44.4, and 49.2 g plant ${ }^{-1}$ for Variants 1, 2, 3 and 4, respectively (data not shown).

The retarding effect of $\mathrm{Zn}$ deficiency (Variant 2) on the maize growth was not strong $-13 \%$ reduction in fresh mass compared to control, but this was not a surprise, because plant development at that stage depends, at least, partially on the seed reserves. The foliar application of $\mathrm{ZnO}$ containing fertiliser tended to increase to some extent $(6 \%)$ the growth in the fresh mass of $\mathrm{Zn}$-deficient maize plants (Variant 3) as compared with those in Variant 2 (data not shown). The application of $\mathrm{ZnHN}$ fertiliser (Variant 4) completely compensates for the lag in its growth and the results (48.1 versus 49.2 g plant $^{-1}$ of control - Variant 1) are statistically indistinguishable at $\mathrm{P}<0.05$. The root system of all plants was well developed (Figure 2C).

The maize plants grown in $\mathrm{Zn}$-deficiency were distinguished by visual chlorotic symptoms of the leaves. The yellowing of the leaves was more expressed between the middle part and the base of the lamina. Some bronzing spots appeared on the younger leaves, too. The mentioned symptoms are similar to those described in the literature (Drissi et al., 2015), but some exceptions also exist. Zn deficiency of maize plants may induce stunted growth due to the shortening of the internodes, which was not the case here. White bands on both sides of the leaf midrib, accepted as a typical symptom of $\mathrm{Zn}$ deficiency, were missing.

The Zn-deficient plants showed significantly decreased leaf gas exchange parameters (Table 2).

The net photosynthetic rate (A) of Zn-deficient plants (Variant 2) was reduced by $49 \%$, the transpiration rate $(\mathrm{E})$ - by $36 \%$ and the stomatal conductance $\left(g_{s}\right)$ - by $40 \%$. The relatively equal repression of these parameters indicates that stomatal limitation could be one of the leading factors for photosynthesis inhibition. Our results correspond to those of Mattiello et al. (2015), who found that zinc deficiency significantly decreased $\mathrm{A}$ and $\mathrm{g}_{\mathrm{s}}$ in maize plants. However, a strong improvement of leaf gas exchange was observed in Zn-deficient plants (Variants 2 and 3) after the application of both $\mathrm{Zn}$-containing fertilisers. The values of $\mathrm{A}, \mathrm{E}$ and $\mathrm{g}_{\mathrm{s}}$ of $\mathrm{ZnO}$-fertilized plants (Variant 3) were significantly higher than those of untreated Zn-deficient ones (Variant 2) by 49, 14 and 33\%, respectively, but still smaller as compared with those of the control plants. The effect of $\mathrm{ZnHN}$ was bigger than $\mathrm{ZnO}$, leading to almost complete restoration of the leaf gas exchange of $\mathrm{Zn}$-deficient maize plants in Variant 4. The application of this fertiliser improved A by $78 \%$ accompanied by 55 and $67 \%$ enhancement of $\mathrm{E}$ and $\mathrm{g}_{\mathrm{s}}$, respectively, as compared with $\mathrm{Zn}$-deficient plants (Variant 2).

These results confirm the findings of Liu et al. (2020) that supplemental foliar $\mathrm{Zn}$ application improved the leaf gas exchange of maize plants. The stronger recovering effect of the $\mathrm{ZnHN}$ application than the $\mathrm{ZnO}$ ones on the leaf gas exchange could be due to

Table 2. Influence of $\mathrm{Zn}$ deficiency and foliar application by $\mathrm{Zn}$ containing fertilisers on leaf gas exchange parameters of young maize plants.

\begin{tabular}{|c|c|c|c|}
\hline Variant & $A^{*}$ & $E$ & $\mathrm{~g}_{\mathrm{s}}$ \\
\hline 1 & $12.21 \pm 1.00^{\mathrm{a}}$ & $0.76 \pm 0.05^{\mathrm{a}}$ & $0.05 \pm 0.00^{\mathrm{a}}$ \\
\hline 2 & $6.26 \pm 0.88^{c}$ & $0.49 \pm 0.06^{\mathrm{b}}$ & $0.03 \pm 0.00^{\mathrm{b}}$ \\
\hline 3 & $9.30 \pm 0.79^{b}$ & $0.56 \pm 0.02^{b}$ & $004 \pm 0.01^{\mathrm{a}}$ \\
\hline 4 & $11.14 \pm 0.20^{\mathrm{a}}$ & $0.76 \pm 0.01^{\mathrm{a}}$ & $0.05 \pm 0.00^{\mathrm{a}}$ \\
\hline $\begin{array}{l}\text { *The data pre } \\
\text { column are s } \\
\mathrm{s}^{-1} \text { ); E, transp } \\
\text { Variant 2, Zn- } \\
+ \text { ZnHN. }\end{array}$ & $\begin{array}{l}\text { are sample means } \\
\text { tly different from } \\
\text { ate (mmol } \mathrm{H}_{2} \mathrm{O} \mathrm{m}{ }^{-} \\
\text {t plants; Variant } 3 \text {, }\end{array}$ & $\begin{array}{l}\text { ation. }{ }^{a-c} \text { Means w } \\
0.05 \text { ). A, net pho } \\
\text { tal conductance } \\
\text { ants + Zintrac } 70\end{array}$ & $\begin{array}{l}\text { tetters in the sa } \\
\text { rate ( } \text { mol } \mathrm{CO}_{2} \\
\text {-). Variant } 1 \text {, cont } \\
\text {, Zn-deficient pla }\end{array}$ \\
\hline
\end{tabular}

Table 3. Influence of $\mathrm{Zn}$ deficiency and foliar application by $\mathrm{Zn}$-containing fertilisers on total chlorophyll content $\left(\mathrm{mg}^{2} \mathrm{~m}^{2}\right)$ and selected chlorophyll fluorescence parameters of young maize plants.

\begin{tabular}{|c|c|c|c|c|c|}
\hline \multirow[t]{2}{*}{ Variant } & \multicolumn{5}{|c|}{ Chlorophyll fluorescence parameters* } \\
\hline & Total chlorophyl & $\mathrm{F}_{\mathrm{v}} / \mathrm{F}_{\mathrm{m}}$ & ETR & $\mathbf{q P}$ & $\mathbf{q} \mathbf{N}$ \\
\hline 1 & $200 \pm 15^{\mathrm{a}}$ & $0.76^{\mathrm{a}}$ & $40.3^{\mathrm{b}}$ & $0.409^{b}$ & $0.341^{\mathrm{a}}$ \\
\hline 2 & $164 \pm 11^{b}$ & $0.72^{\mathrm{a}}$ & $27.8^{\mathrm{c}}$ & $0.308^{c}$ & $0.250^{b}$ \\
\hline 3 & $175 \pm 8^{b}$ & $0.75^{\mathrm{a}}$ & $38.9^{\mathrm{b}}$ & $0.450^{b}$ & $0.374^{\mathrm{a}}$ \\
\hline 4 & $182 \pm 10^{b}$ & $0.75^{\mathrm{a}}$ & $59.6^{\mathrm{a}}$ & $0.665^{\mathrm{a}}$ & $0.310^{\mathrm{a}}$ \\
\hline
\end{tabular}

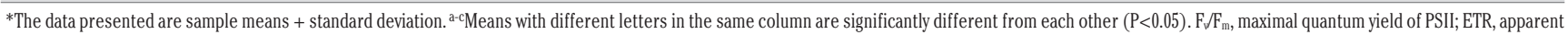
electron transport rate ( $\mu \mathrm{mol} \mathrm{m} \mathrm{m}^{-2} \mathrm{~s}^{-1}$ ); qP, photochemical quenching; qN, non-photochemical quenching of chlorophyll fluorescence. Variant 1, control; Variant 2, Zn-deficient plants; Variant 3, Zn-deficient plants + Zintrac 700; Variant 4, Zn-deficient plants + ZnHN. 
different reasons, including the higher leaf $\mathrm{Zn}$ content as compared with that of the plants in Variant 3.

Zn deficiency decreased significantly $(18 \%)$ the total chlorophyll content of the maize plants (Variant 2) (Table 3). In the same time, the maximal quantum yield of PSII $\left(\mathrm{F}_{\mathrm{v}} / \mathrm{F}_{\mathrm{m}}\right)$ of these plants was slightly and insignificantly decreased. The $F_{v} / F_{m}$ (decreased) value was a bit lower but close to the range typical for healthy plants - 0.75 to 0.83 (Bolhàr-Nordenkampf and Öquist, 1993).

The apparent photosynthetic electron transport rate (ETR) of Zn-deficient plants (Variant 2) was reduced by $31 \%$. The quenching analysis showed that both photochemical quenching (qP) and non-photochemical quenching ( $\mathrm{qN})$ in these plants were diminished, by 25 and $27 \%$, respectively. As qP represents the relative part of open reactive centres of the PSII, its decrease could be explained as the $\mathrm{Zn}$ deficiency-induced lowering of these centres. The $\mathrm{qN}$ represents the heat dissipation losses and normally its values increased in stress situations. Here, the $\mathrm{qN}$ values in $\mathrm{Zn}$-deficient plants surprisingly decreased. The adverse influence of $\mathrm{Zn}$ deficiency on the light stage of photosynthesis is probably one of the possible reasons for the decreased net photosynthetic rate (A) of the maize plants.

The application of both $\mathrm{Zn}$-containing fertilisers significantly improved both chlorophyll content and the primary photochemistry of Zn-deficient maize plants (Variant 3 and Variant 4). The positive effect of $\mathrm{Zn}$-containing fertilisers was more pronounced in the plants of Variant 4. Here, the application of $\mathrm{ZnHN}$ resulted in higher chlorophyll content $(11 \%)$ as compared with the Zn-deficient plants without foliar fertilisation (Variant 2). The positive effect of $\mathrm{ZnHN}$ on both ETR and qP was stronger and their values were twice bigger than the corresponding values in the plants from Variant 2.

\section{Dynamic of zinc and micro- and macroelements con- centration in plants organs}

The concept concerning the transport of zinc in plants is contradictory. Some authors report that zinc can be transported in the phloem, while others claim that such transport does not occur (Haslett et al., 2001). To obtain more information on this issue in the case of Zn-deficiency we tracked the dynamics of zinc movement in the roots, stems and leaves of maize throughout the growing period. As the zinc uptake is associated with the presence of other elements, we expanded the investigation by tracking the change in concentrations of the main micro and macronutrients. In analysing the results, it should be borne in mind that zinc and other nutrients in the soil, unlike the artificial nutrient solution, are in different forms, with a very small fraction being in the form of plant-available form.

\section{Dynamic of $Z$ n concentration in plants organs}

Understanding the dynamics of zinc uptake by maize is the basis for determining the sufficient stages of its accumulation in the plants. It is generally accepted that in the initial period of maize growth the accumulation of this element is low (Potarzycki, 2010). On the other hand, the adequate zinc supply during the first 24 days of vegetation increased the growth rate, which is reflected both by the increased height of the plants as well as dry matter con-

Table 4. Content of micro- and macronutrients in the roots of the plants before moving to Research Farm.

\begin{tabular}{|c|c|c|c|c|c|c|c|c|}
\hline Variant & $\begin{array}{c}\mathrm{Zn}^{*} \\
\mathrm{mg} \mathrm{kg}^{-1}\end{array}$ & $\begin{array}{c}\mathrm{Cu}, \\
\mathrm{mg} \mathrm{kg}^{-1}\end{array}$ & $\begin{array}{c}\mathrm{Fe}, \\
\mathrm{mg} \mathrm{kg}^{-1}\end{array}$ & $\begin{array}{c}\text { Mn, } \\
\text { mg kg-1 }\end{array}$ & $\begin{array}{l}\mathrm{P}, \\
\%\end{array}$ & $\begin{array}{l}\mathrm{K}, \\
\%\end{array}$ & $\begin{array}{c}\mathrm{Ca}, \\
\%\end{array}$ & $\begin{array}{c}\mathrm{Mg}, \\
\%\end{array}$ \\
\hline 1 & $17.52 \pm 0.52^{\mathrm{a}}$ & $28.12 \pm 0.75^{c}$ & $118.06 \pm 3.26^{\mathrm{b}}$ & $2.40 \pm 0.10^{\mathrm{a}}$ & $0.55 \pm 0.02^{b}$ & $1.92 \pm 0.06^{\mathrm{c}}$ & $0.36 \pm 0.01^{\mathrm{c}}$ & $0.30 \pm 0.01^{\mathrm{b}}$ \\
\hline 2 & $10.10 \pm 0.40^{\mathrm{d}}$ & $27.02 \pm 0.86^{\mathrm{c}}$ & $87.52 \pm 2.86^{\mathrm{c}}$ & $2.52 \pm 0.08^{\mathrm{a}}$ & $0.50 \pm 0.01^{\mathrm{c}}$ & $2.30 \pm 0.05^{b}$ & $0.42 \pm 0.02^{b}$ & $0.27 \pm 0.01^{\mathrm{c}}$ \\
\hline 3 & $12.21 \pm 0.44^{c}$ & $31.34 \pm 0.92^{\mathrm{b}}$ & $117.71 \pm 3.02^{b}$ & $1.91 \pm 0.06^{\mathrm{b}}$ & $0.65 \pm 0.02^{\mathrm{a}}$ & $2.80 \pm 0.06^{\mathrm{a}}$ & $0.52 \pm 0.02^{\mathrm{a}}$ & $0.34 \pm 0.02^{\mathrm{a}}$ \\
\hline 4 & $15.72 \pm 0.50^{b}$ & $35.62 \pm 1.02^{\mathrm{a}}$ & $146.10 \pm 3.64^{\mathrm{a}}$ & $2.42 \pm 0.11^{\mathrm{a}}$ & $0.43 \pm 0.02^{\mathrm{d}}$ & $1.99 \pm 0.04^{\mathrm{c}}$ & $0.48 \pm 0.02^{\mathrm{a}}$ & $0.32 \pm 0.02^{\mathrm{ab}}$ \\
\hline
\end{tabular}

*The data presented are sample means + standard deviation. ${ }^{\text {a-d }} \mathrm{d}$ Means with different letters in the same column are significantly different from each other ( $\left.\mathrm{P}<0.05\right)$. Variant 1 , control; Variant 2 , Zn-deficient plants Variant 3, Zn-deficient plants + Zintrac 700; Variant 4, Zn-deficient plants + ZnHN.

Table 5. Content of micro- and macronutrients in the stems of the plants before moving to Research Farm.

\begin{tabular}{ccccccccc} 
Variant & $\begin{array}{c}\mathrm{Zn} \mathbf{n}^{*}, \\
\mathrm{mg} \mathrm{kg}^{-1}\end{array}$ & $\begin{array}{c}\mathrm{Cu}, \\
\mathrm{mg} \mathrm{kg}^{-1}\end{array}$ & $\begin{array}{c}\mathrm{Fe}, \\
\mathrm{mg} \mathrm{kg}^{-1}\end{array}$ & $\begin{array}{c}\mathrm{Mn}, \\
\mathrm{mg} \mathrm{kg-1}\end{array}$ & $\begin{array}{c}\mathrm{P}, \\
\%\end{array}$ & $\begin{array}{c}\mathrm{K}, \\
\%\end{array}$ & $\begin{array}{c}\mathrm{Ca}, \\
\%\end{array}$ & $\begin{array}{c}\mathrm{Mg}, \\
\%\end{array}$ \\
1 & $23.30 \pm 0.74^{\mathrm{a}}$ & $4.92 \pm 0.26^{\mathrm{b}}$ & $30.50 \pm 0.98^{\mathrm{a}}$ & $10.12 \pm 0.32^{\mathrm{a}}$ & $0.35 \pm 0.01^{\mathrm{c}}$ & $3.28 \pm 0.08^{\mathrm{b}}$ & $0.62 \pm 0.03^{\mathrm{a}}$ & $0.29 \pm 0.01^{\mathrm{c}}$ \\
2 & $8.22 \pm 0.32^{\mathrm{d}}$ & $4.01 \pm 0.25^{\mathrm{c}}$ & $25.72 \pm 0.86^{\mathrm{b}}$ & $6.40 \pm 0.22^{\mathrm{c}}$ & $0.41 \pm 0.02^{\mathrm{b}}$ & $2.73 \pm 0.06^{\mathrm{c}}$ & $0.51 \pm 0.02^{\mathrm{b}}$ & $0.26 \pm 0.01^{\mathrm{d}}$ \\
\hline 3 & $17.02 \pm 0.64^{\mathrm{c}}$ & $5.70 \pm 0.28^{\mathrm{a}}$ & $30.62 \pm 1.02^{\mathrm{a}}$ & $7.32 \pm 0.36^{\mathrm{b}}$ & $0.51 \pm 0.03^{\mathrm{a}}$ & $3.91 \pm 0.08^{\mathrm{a}}$ & $0.60 \pm 0.03^{\mathrm{a}}$ & $0.39 \pm 0.02^{\mathrm{a}}$ \\
4 & $21.06 \pm 0.72^{\mathrm{b}}$ & $5.22 \pm 0.26^{\mathrm{ab}}$ & $30.44 \pm 0.96^{\mathrm{a}}$ & $7.04 \pm 0.32^{\mathrm{b}}$ & $0.40 \pm 0.02^{\mathrm{b}}$ & $2.83 \pm 0.04^{\mathrm{c}}$ & $0.45 \pm 0.02^{\mathrm{c}}$ & $0.33 \pm 0.01^{\mathrm{b}}$ \\
\hline
\end{tabular}

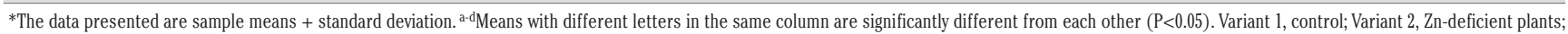
Variant 3, Zn-deficient plants + Zintrac 700; Variant 4, Zn-deficient plants + ZnHN.

Table 6. Content of micro- and macronutrients in the leaves of the plants before moving to Research Farm.

\begin{tabular}{ccccccccc} 
Variant & $\begin{array}{c}\mathrm{Zn} *^{*}, \\
\mathrm{mg} \mathrm{kg}^{-1}\end{array}$ & $\begin{array}{c}\mathrm{Cu}, \\
\mathrm{mg} \mathrm{kg}^{-1}\end{array}$ & $\begin{array}{c}\mathrm{Fe}, \\
\mathrm{mg} \mathrm{kg}^{-1}\end{array}$ & $\begin{array}{c}\mathrm{Mn}, \\
\mathrm{mg} \mathrm{kg-1}\end{array}$ & $\begin{array}{c}\mathrm{P}, \\
\%\end{array}$ & $\begin{array}{c}\mathrm{K}, \\
\%\end{array}$ & $\begin{array}{c}\mathrm{Ca}, \\
\%\end{array}$ & $\begin{array}{c}\mathrm{Mg}, \\
\%\end{array}$ \\
1 & $17.25 \pm 0.58^{\mathrm{b}}$ & $14.44 \pm 0.42^{\mathrm{c}}$ & $83.02 \pm 2.06^{\mathrm{a}}$ & $13.42 \pm 0.30^{\mathrm{b}}$ & $0.32 \pm 0.01^{\mathrm{c}}$ & $2.31 \pm 0.06^{\mathrm{b}}$ & $0.39 \pm 0.02^{\mathrm{b}}$ & $0.26 \pm 0.02^{\mathrm{a}}$ \\
2 & $8.20 \pm 0.34^{\mathrm{d}}$ & $16.82 \pm 0.39^{\mathrm{b}}$ & $70.41 \pm 1.98^{\mathrm{c}}$ & $10.72 \pm 0.28^{\mathrm{c}}$ & $0.41 \pm 0.02^{\mathrm{b}}$ & $2.11 \pm 0.04^{\mathrm{c}}$ & $0.53 \pm 0.02^{\mathrm{a}}$ & $0.22 \pm 0.01^{\mathrm{b}}$ \\
\hline 3 & $15.02 \pm 0.56^{\mathrm{c}}$ & $18.01 \pm 0.40^{\mathrm{a}}$ & $84.30 \pm 2.20^{\mathrm{a}}$ & $15.20 \pm 0.32^{\mathrm{a}}$ & $0.51 \pm 0.02^{\mathrm{a}}$ & $2.60 \pm 0.06^{\mathrm{a}}$ & $0.58 \pm 0.04^{\mathrm{a}}$ & $0.29 \pm 0.02^{\mathrm{a}}$ \\
4 & $21.22 \pm 0.66^{\mathrm{a}}$ & $17.60 \pm 0.36^{\mathrm{ab}}$ & $75.36 \pm 1.86^{\mathrm{b}}$ & $12.96 \pm 0.32^{\mathrm{b}}$ & $0.40 \pm 0.01^{\mathrm{b}}$ & $2.58 \pm 0.06^{\mathrm{a}}$ & $0.53 \pm 0.02^{\mathrm{a}}$ & $0.28 \pm 0.01^{\mathrm{a}}$ \\
\hline
\end{tabular}

${ }^{*}$ The data presented are sample means + standard deviation. ${ }^{\text {a-d }}{ }^{\mathrm{M}}$ Means with different letters in the same column are significantly different from each other $(\mathrm{P}<0.05)$. Variant 1 , control; Variant 2, Zn-deficient plants; Variant 3, Zn-deficient plants + Zintrac 700; Variant 4, Zn-deficient plants + ZnHN . 
tent (Furlani et al., 2005). On the basis of our results (Ivanov et al., 2019) and literature data (Jones et al., 1991) we accepted $15 \mathrm{mg}$ $\mathrm{kg}^{-1}$ as sufficient zinc levels during this phase of plant development.

Tables 4 to 6 present the results of zinc and the main micro and macro elements content in the roots, stems and leaves of the plants at the end of the growth period in the climatic chamber.

It is noteworthy that the organs of Variant 2 plants contain some amount of zinc, despite its absence in the nutrient solution. The source of this zinc is corn kernels (14.81 mg kg-1) and some contamination through the salts used for nutrient solution preparation should not be excluded.

As it is expected the zinc content in the roots of plants of Variant $2\left(10.10 \mathrm{mg} \mathrm{kg}^{-1}\right)$ was lowest and in the roots of plants of Variant 1 - highest $\left(17.52 \mathrm{mg} \mathrm{kg}^{-1}\right)$. The zinc content of the plant roots of Varians $3\left(12.21 \mathrm{mg} \mathrm{kg}^{-1}\right)$ and $4\left(15.72 \mathrm{mg} \mathrm{kg}^{-1}\right)$ was medial. The same tendency is observed in the stems and leaves of plants. In this case, however, the zinc content of the stems and leaves of the plants of Variant 3 (17.02 and $\left.15.02 \mathrm{mg} \mathrm{kg}^{-1}\right)$ and Variant 4 (21.06 and $\left.21.22 \mathrm{mg} \mathrm{kg}^{-1}\right)$ is significantly higher than that of Variant $2\left(8.22\right.$ and $\left.8.20 \mathrm{mg} \mathrm{kg}^{-1}\right)$. This indicates that the accumulation of zinc was followed by its remobilization from the leaves to other plant organs. The results show that the zinc content in organs of the plants of Variant 4 is higher than that of Variant 3. This fact can be explained by its better accumulation by $\mathrm{ZnHN}$ than by $\mathrm{ZnO}$ due to the lower solubility of the oxide and this agrees with the results of Li et al., 2012. Zinc content in all organs of
Variant 2 plants is well below that in organs of other plants which explains the observed deficiency symptoms.

The results for the zinc concentration in the plant organs after harvesting, presented in Tables 7 to 9, are surprising.

Contrary to expectations, its content in plant roots varies widely from $20.38 \mathrm{mg} \mathrm{kg}^{-1}$ in Variant 4 to $42.10 \mathrm{mg} \mathrm{kg}^{-1}$ in Variant 2. In stems and leaves, the concentration of zinc is the lowest in the control, while in the other variants the values are close. Generally, its content in plant organs of all variants is within the normal range for this stage of plants development (Jones et al., 1991). The results presented show that zinc deficiency of the first stage of plant development is fully compensated after being moved to the field. The reasons for this compensatory effect, in our opinion, are 2: i) at the end of May and beyond, temperatures are high and plants can meet their nutritional requirements through the root system (Figure 2); and ii) zinc accumulation substantially intensifies during the fast stem elongation period (Potarzycki, 2010) and at the time of tasselling (Grzebisz et al., 2008a).

\section{Dynamic of micro- and macroelements concentration in plants organs}

The healthy development of maize plants requires a balanced provision of essential nutrients and their dynamics in the context of zinc deficiency being important. According to literature (Jones et al., 1991; Baran et al., 2012), the optimal concentrations of the essential nutrient in maize at eight leaves stage have been assumed to be: $\mathrm{P}-0.3$ to $0.6 \% ; \mathrm{K}-0.3$ to $0.45 \% ; \mathrm{Mg}-0.2$ to $0.6 \%$ and $\mathrm{Ca}$

Table 7. Content of micro- and macronutrients in the roots of the plants after harvesting.

\begin{tabular}{ccccccccc}
\hline Variant & $\begin{array}{c}\mathrm{Zn}^{*}, \\
\mathrm{mg} \mathrm{kg}^{-1}\end{array}$ & $\begin{array}{c}\mathrm{Cu}, \\
\mathrm{mg} \mathrm{kg}^{-1}\end{array}$ & $\begin{array}{c}\mathrm{Fe}, \\
\mathrm{mg} \mathrm{kg}^{-1}\end{array}$ & $\begin{array}{c}\mathrm{Mn}, \\
\mathrm{mg} \mathrm{kg}\end{array}$ & $\begin{array}{c}\mathrm{P}, \\
\%\end{array}$ & $\begin{array}{c}\mathrm{K}, \\
\%\end{array}$ & $\begin{array}{c}\mathrm{Ca}, \\
\%\end{array}$ & $\begin{array}{c}\mathrm{Mg}, \\
\%\end{array}$ \\
\hline 1 & $37.50 \pm 1.04^{\mathrm{b}}$ & $9.06 \pm 0.27^{\mathrm{c}}$ & $1240 \pm 38^{\mathrm{c}}$ & $28.42 \pm 0.62^{\mathrm{d}}$ & $0.05 \pm 0.01^{\mathrm{a}}$ & $0.38 \pm 0.02^{\mathrm{a}}$ & $0.20 \pm 0.01^{\mathrm{a}}$ & $0.98 \pm 0.04^{\mathrm{b}}$ \\
2 & $42.10 \pm 0.98^{\mathrm{a}}$ & $14.82 \pm 0.32^{\mathrm{a}}$ & $1910 \pm 42^{\mathrm{a}}$ & $36.90 \pm 0.90^{\mathrm{a}}$ & $0.05 \pm 0.01^{\mathrm{a}}$ & $0.36 \pm 0.02^{\mathrm{a}}$ & $0.22 \pm 0.01^{\mathrm{a}}$ & $0.80 \pm 0.03^{\mathrm{c}}$ \\
\hline 3 & $33.82 \pm 0.88^{\mathrm{c}}$ & $12.40 \pm 0.28^{\mathrm{b}}$ & $1284 \pm 42^{\mathrm{bc}}$ & $30.12 \pm 0.84^{\mathrm{c}}$ & $0.06 \pm 0.01^{\mathrm{a}}$ & $0.40 \pm 0.03^{\mathrm{a}}$ & $0.21 \pm 0.01^{\mathrm{a}}$ & $1.16 \pm 0.04^{\mathrm{a}}$ \\
4 & $20.38 \pm 0.84^{\mathrm{d}}$ & $7.78 \pm 0.30^{\mathrm{d}}$ & $1361 \pm 36^{\mathrm{b}}$ & $34.01 \pm 0.88^{\mathrm{b}}$ & $0.04 \pm 0.01^{\mathrm{a}}$ & $0.31 \pm 0.02^{\mathrm{b}}$ & $0.22 \pm 0.01^{\mathrm{a}}$ & $0.98 \pm 0.03^{\mathrm{b}}$ \\
\hline
\end{tabular}

*The data presented are sample means + standard deviation. ${ }^{\mathrm{a}-\mathrm{d}} \mathrm{Means}$ with different letters in the same column are significantly different from each other $(\mathrm{P}<0.05)$. Variant 1 , control; Variant 2 , Zn-deficient plants; Variant 3, Zn-deficient plants + Zintrac 700; Variant 4, Zn-deficient plants + ZnHN.

Table 8. Content of micro- and macronutrients in the stems of the plants after harvesting.

\begin{tabular}{ccccccccc} 
Variant & $\begin{array}{c}\mathrm{Zn}^{*}, \\
\mathrm{mg} \mathrm{kg}^{-1}\end{array}$ & $\begin{array}{c}\mathrm{Cu}, \\
\mathrm{mg} \mathrm{kg}^{-1}\end{array}$ & $\begin{array}{c}\mathrm{Fe}, \\
\mathrm{mg} \mathrm{kg}^{-1}\end{array}$ & $\begin{array}{c}\mathrm{Mn}, \\
\mathrm{mg} \mathrm{kg}\end{array}$ & $\begin{array}{c}\mathrm{P}, \\
\%\end{array}$ & $\begin{array}{c}\mathrm{K}, \\
\%\end{array}$ & $\begin{array}{c}\mathrm{Ca}, \\
\%\end{array}$ & $\begin{array}{c}\mathrm{Mg}, \\
\%\end{array}$ \\
\hline 1 & $15.88 \pm 0.42^{\mathrm{c}}$ & $3.40 \pm 0.11^{\mathrm{a}}$ & $27.42 \pm .81^{\mathrm{a}}$ & $10.04 \pm 0.32^{\mathrm{d}}$ & $0.22 \pm 0.01^{\mathrm{a}}$ & $1.81 \pm 0.06^{\mathrm{b}}$ & $0.15 \pm 0.01^{\mathrm{b}}$ & $0.18 \pm 0.01^{\mathrm{a}}$ \\
2 & $23.65 \pm 0.68^{\mathrm{b}}$ & $2.11 \pm 0.08^{\mathrm{c}}$ & $27.30 \pm 0.96^{\mathrm{a}}$ & $17.40 \pm 0.44^{\mathrm{a}}$ & $0.23 \pm 0.01^{\mathrm{a}}$ & $1.12 \pm 0.04^{\mathrm{c}}$ & $0.14 \pm 0.01^{\mathrm{b}}$ & $0.16 \pm 0.01^{\mathrm{b}}$ \\
\hline 3 & $25.62 \pm 0.82^{\mathrm{b}}$ & $3.00 \pm 0.10^{\mathrm{b}}$ & $28.22 \pm 0.88^{\mathrm{a}}$ & $11.52 \pm 0.28^{\mathrm{c}}$ & $0.24 \pm 0.01^{\mathrm{a}}$ & $1.76 \pm 0.04^{\mathrm{b}}$ & $0.16 \pm 0.01^{\mathrm{b}}$ & $0.18 \pm 0.01^{\mathrm{a}}$ \\
4 & $28.94 \pm 0.92^{\mathrm{a}}$ & $3.12 \pm 0.12^{\mathrm{b}}$ & $28.40 \pm 0.90^{\mathrm{a}}$ & $12.91 \pm 0.28^{\mathrm{b}}$ & $0.18 \pm 0.01^{\mathrm{b}}$ & $2.22 \pm 0.08^{\mathrm{a}}$ & $0.20 \pm 0.01^{\mathrm{a}}$ & $0.20 \pm 0.01^{\mathrm{a}}$ \\
\hline
\end{tabular}

*The data presented are sample means + standard deviation. ${ }^{\text {a-d }}$ Means with different letters in the same column are significantly different from each other (P<0.05). Variant 1 , control; Variant 2 , Zn-deficient plants; Variant 3, Zn-deficient plants + Zintrac 700; Variant 4, Zn-deficient plants + ZnHN.

Table 9. Content of micro- and macronutrients in the leaves of the plants after harvesting.

\begin{tabular}{|c|c|c|c|c|c|c|c|c|}
\hline Variant & $\begin{array}{c}\text { Zn*, } \\
\text { mg kg-1 }\end{array}$ & $\begin{array}{c}\mathrm{Cu}, \\
\mathrm{mg} \mathrm{kg-1}\end{array}$ & $\begin{array}{c}\text { Fe, } \\
\mathrm{mg} \mathrm{kg}^{-1}\end{array}$ & 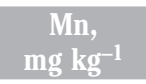 & $\begin{array}{l}\mathbf{P}, \\
\%\end{array}$ & $\begin{array}{l}\mathrm{K}, \\
\%\end{array}$ & $\begin{array}{l}\mathrm{Ca}, \\
\%\end{array}$ & $\begin{array}{c}\mathrm{Mg}, \\
\%\end{array}$ \\
\hline 1 & $18.44 \pm 0.68^{b}$ & $9.60 \pm 0.28^{a}$ & $137.50 \pm 4.12^{b}$ & $95.2 \pm 2.46^{\mathrm{c}}$ & $0.16 \pm 0.01^{\mathrm{a}}$ & $0.57 \pm 0.2^{\mathrm{a}}$ & $0.65 \pm 0.03^{\mathrm{a}}$ & $0.28 \pm 0.02^{\mathrm{a}}$ \\
\hline 2 & $27.60 \pm 0.92^{\mathrm{a}}$ & $4.72 \pm 0.20^{b}$ & $102.02 \pm 3.86^{\mathrm{c}}$ & $121.0 \pm 4.02^{\mathrm{a}}$ & $0.18 \pm 0.01^{\mathrm{a}}$ & $0.32 \pm 0.01^{\mathrm{c}}$ & $0.49 \pm 0.01^{b}$ & $0.19 \pm 0.01^{b}$ \\
\hline 3 & $28.12 \pm 0.88^{a}$ & $9.62 \pm 0.26^{\mathrm{a}}$ & $178.12 \pm 5.26^{\mathrm{a}}$ & $93.5 \pm 3.04^{c}$ & $0.17 \pm 0.01^{\mathrm{a}}$ & $0.51 \pm 0.02^{\mathrm{b}}$ & $0.64 \pm 0.02^{\mathrm{a}}$ & $0.31 \pm 0.01^{\mathrm{a}}$ \\
\hline 4 & $26.62 \pm 0.80^{\mathrm{a}}$ & $9.51 \pm 0.28^{a}$ & $161.24 \pm 5.04^{\mathrm{a}}$ & $113.1 \pm 3.12^{b}$ & $0.14 \pm 0.01^{b}$ & $0.32 \pm 0.01^{\mathrm{c}}$ & $0.65 \pm 0.02^{\mathrm{a}}$ & $0.32 \pm 0.02^{\mathrm{a}}$ \\
\hline
\end{tabular}

*The data presented are sample means + standard deviation. ${ }^{\text {acc } M e a n s ~ w i t h ~ d i f f e r e n t ~ l e t t e r s ~ i n ~ t h e ~ s a m e ~ c o l u m n ~ a r e ~ s i g n i f i c a n t l y ~ d i f f e r e n t ~ f r o m ~ e a c h ~ o t h e r ~}(\mathrm{P}<0.05)$. Variant 1 , control; Variant 2 , Zn-deficient plants; Variant 3, Zn-deficient plants + Zintrac 700; Variant 4, Zn-deficient plants + ZnHN. 
- 0.3 to $1.0 \%$ (all data refer to dry matter). The results presented in Tables 2 to 4 are in agreement with this understanding and do not indicate a significant impact of the Zn-deficiency on the concentration of macronutrients in maize organs. However, the lower $\mathrm{Mg}$ content in the plants of variants 1 is notable compared to the plants of variants 2,3 and 4 . This also explains the results of physiological studies. This trend continues up to the ripening of the plants (Tables 5 to 7). The concentration of the basic nutrients $\mathrm{K}$ and $\mathrm{P}$ decreases dramatically (mainly in roots) during the harvest. The amount of all nutrients uptake increases by increasing plant growth but their concentration decreases in plant tissues as a result of dilution effect and redistribution from the vegetative organs to the developing kernels (Potarzycki, 2010).

Copper content is lowest in the leaves of young plants and highest in the roots. Its accumulation by all organs of plants from Variants 2 is snookered compared to the plants of Variants 3 and 4. The reason for this is the negative interaction between zinc and copper due to the effect of antagonism and the same membrane transport (Rengel and Graham, 1995; Abd El-Hady et al., 2007; Moustakas et al., 2011). This trend persists up to harvest, but the main amount is concentrated in the roots. Similar results were found for iron content, in which case its concentration is lowest in the stems and highest in the roots. The result is in agreement with the acceptance that zinc deficiency leads to iron deficiency, due to the prevention of the transfer of iron from root to shoot in zinc deficiency conditions (Rengel et al., 1998; Mousavi, 2011). During the second stage of plant development, a significant amount of iron is retained in the roots. The concentration of both elements is above the sufficient levels in both maize growth periods (Jones et al., 1991).

Adiloglu et al. (2016) reported that the application of $\mathrm{Zn}$ increased Mn concentration in corn plants. On the opposite opinion, Imtiaz et al. (2003), who researched interaction of zinc with other trace elements had established that, with increasing $\mathrm{Zn}$ applications, Mn concentration in wheat shoot tissue decreases. Our results are in agreement with the results of Adiloglu et al. (2016). In the first period of maize growth, the content of manganese in the stems and leaves of plants from Variant 2 was below the sufficient level (Jones et al., 1991). In the second growth period, this deficit was fully compensated (Tables 5 to 7 ).

\section{Impact of foliar zinc fertilisation on grain structural components}

Within the mineral-related abiotic stresses, $\mathrm{Zn}$ deficiency is one of the most widespread limiting factors to maize production (Hacisalihoglu and Kochian, 2003). This is confirmed by the results of our experiment. Picture of corn cobs, collected after harvesting is presented in Figure 3. A drastic difference in grain productivity between variants can be seen. Only three of the six plants from Variant 2 formed cobs, while for the control they are five and
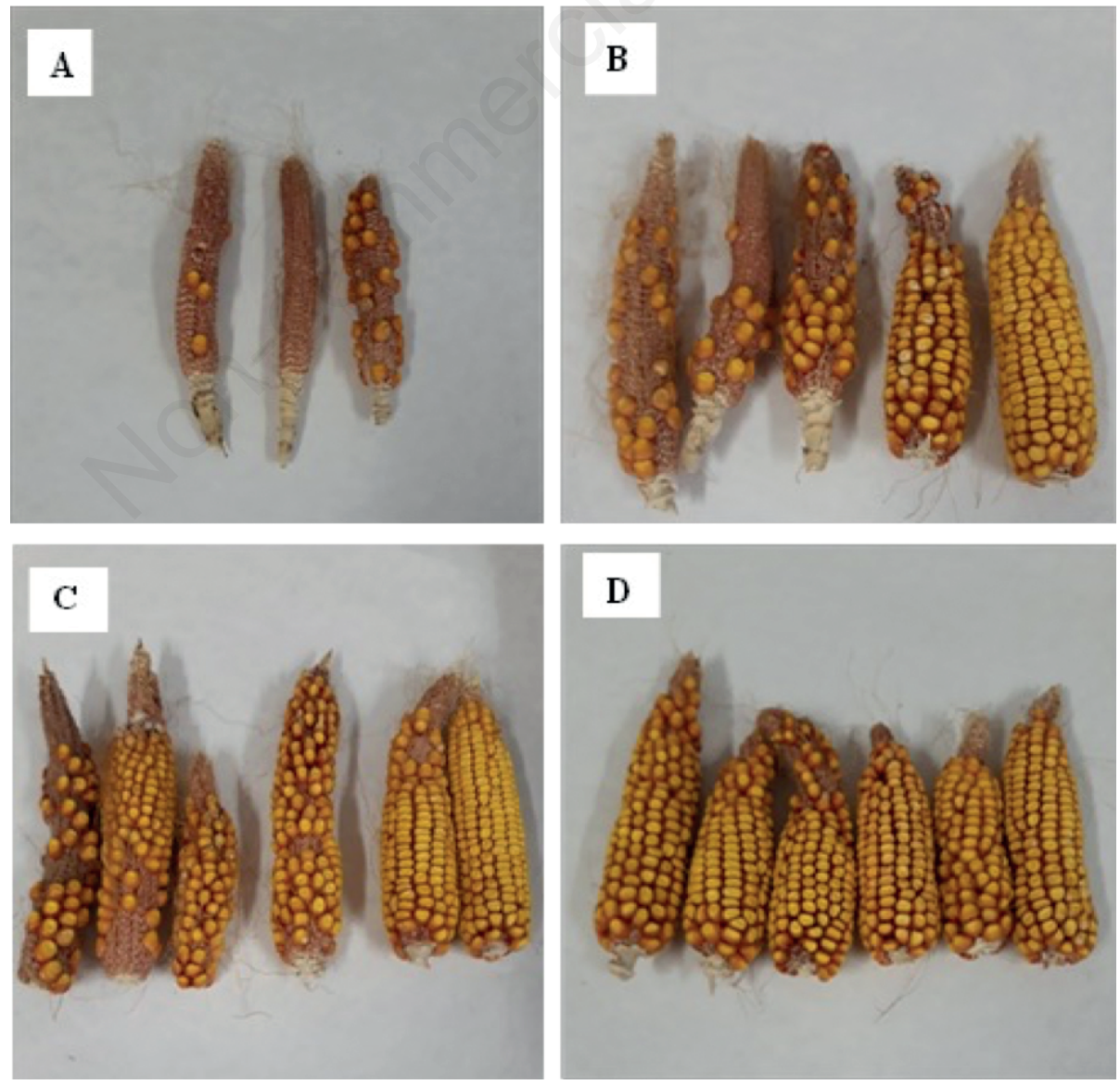

Figure 3. Picture of corn cobs, collected after harvesting: A) Variant II; B) Variant 1 (Control); C) Variant III; D) Variant IV. 
Table 10. Average data for grain structural components.

\begin{tabular}{ccccc} 
Variant & Dry matter & Protein content, \% & Fat content, \% & Starch content, \% \\
1 & $88.99^{\mathrm{a}}$ & $11.40^{\mathrm{a}}$ & $4.43^{\mathrm{a}}$ & $61.62^{\mathrm{b}}$ \\
2 & $89.05^{\mathrm{a}}$ & $9.04^{\mathrm{b}}$ & $4.47^{\mathrm{a}}$ & $69.07^{\mathrm{a}}$ \\
\hline 3 & $88.87^{\mathrm{a}}$ & $9.96^{\mathrm{b}}$ & $4.76^{\mathrm{a}}$ & $65.68^{\mathrm{a}}$ \\
\hline 4 & $88.81^{\mathrm{a}}$ & $9.02^{\mathrm{b}}$ & $4.89^{\mathrm{a}}$ & $66.36^{\mathrm{a}}$ \\
\hline Average & $88.93 \pm 0.11$ & $9.86 \pm 1.12$ & $4.64 \pm 0.22$ & $65.68 \pm 3.08$ \\
\hline
\end{tabular}

a-cValues with different letters in the same column are significantly different from each other $(\mathrm{P}<0.05)$. Variant 1, control; Variant 2, Zn-deficient plants; Variant 3, Zn-deficient plants + Zintrac 700; Variant 4, Zn-deficient plants + ZnHN.

for Variants 3 and 4, six each. The same trend is observed in the number of grains - while in Variant 2 they are nearly absent, in control and Variant 3 two of the cobs are fully developed and in Variant 4 all cobs are fully developed.

The results obtained are a good indicator of the periods of maize growth during which zinc plays an important role in grain productivity. It can confidently be concluded that zinc feeding during the initial growth stages is of great importance and plays a decisive role in the formation of the reproductive organs of maize. The explanation for this is that zinc stimulates the processes of biomass accumulation through increasing the effectiveness of other nutrients, particularly nitrogen, which is an indirect yieldforming function of zinc (Grzebisz et al., 2008b). The main problem is that during this period the soil temperature is low and the root system of the plants is not sufficiently developed. This does not allow them to accumulate the amount of zinc they need at this stage in their development. Soil fertilizing with zinc-containing fertilisers can help, but it cannot completely solve this problem. The application of foliar fertiliser is extremely suitable as its absorption is much faster than from the soil. The advantage of $\mathrm{ZnHN}$ is that its nanoscale crystals remain on the leaf surface for a long time and act as a reservoir for zinc delivery over a long period (Li et al., 2014).

The impact of zinc fertilisation on maize productivity is not in doubt. It is important to know to what extent this also applies to grain structural components. Table 10 presents the results for the main structural components (dry matter, protein, fat and starch) of the grains collected in our experiment.

Presented results show that the differences in the values of grain structural components are smaller than those of the grain productivity. Data for dry matter and fat in grains varied within a narrow range, with no significant $(\mathrm{P}<0.05)$ differences between variants. They do not differ significantly from the values obtained in our previous field experiments with maize. Protein and starch content vary in wider borders. It is noteworthy that the protein content of the corn grains of Variant 1 is greatest and the difference with the other variants is significant at $\mathrm{p}<0.05$ and the content of starch is lower. In the other Variants, the values for the two components are close.

Some authors believe that zinc has a significant effect not only on grain productivity but on grain structural components too (Tahir et al., 2009; Mohsin et al., 2014; Imran and Rehim, 2017). The results obtained in the conditions of our experiment do not give us sufficient reason to confirm this claim. Further research is needed to give a firm opinion on this issue.

\section{Conclusions}

The agronomic response of $\mathrm{Zn}$-deficient young maize plants to foliar fertilisation with nanoscale zinc-containing foliar fertilisers was investigated. The results obtained gave evidence to conclude that:

- both applied zinc fertilisers entirely recover the physiological performance of plants, being zinc hydroxide nitrate superior to commercial $\mathrm{ZnO}$. The reasons for this are two: i) zinc supply at the time of the sufficient period for yield formation; ii) long-term performance of the used fertilisers after spraying. The better results with the use of zinc hydroxy nitrate are due to its better solubility and easier absorption by plants.

- Zn-fertilisation of maize plants during the initial growth stages is of great importance and plays a decisive role in the formation of the reproductive organs of maize. The application of foliar fertilisers is extremely suitable as the possibility of much faster zinc absorption than from the soil.

\section{References}

Abd El-Hady BA, 2007. Effect of zinc application on growth and nutrient uptake of barley plant irrigated with saline water. Res. J. Appl. Sci. 3:431-6.

Adiloglu A, Adiloglu S, 2016. The effect of boron (B) application on the growth and nutrient content of maize in zinc-deficient soils. Bulg. J. Agric. Sci. 12:387-92.

Alloway BJ, 2009. Soil factors associated with zinc deficiency in crops and humans. Environ. Geochem. Health 31:537-48.

Baran A, Jasiewicz C, Tarnawski M, 2012. Effect of bottom sediment supplement to light soil on the content and uptake of macroelements by maize. Ecol. Chem. Eng. A 19:863-72.

Bolhàr-Nordenkampf HR, Öquist G, 1993. Chlorophyll fluorescence as a tool in photosynthesis research. In: Photosynthesis and production in a changing environment. Springer, Dordrecht, pp 193-206.

Broadley M, 2012. Function of nutrients: micronutrients. In: Marschner P (Ed.), Marschner's mineral nutrition of higher plants. 3rd ed. Academic Press, San Diego, CA, USA, pp. 191248.

Broadley MR, White PJ, Hammond JP, Zelko I, Lux A, 2007. Zinc in plants. New Phytol. 173:677-702.

Cakmak I, 2009. Enrichment of fertilisers with zinc: an excellent investment for humanity and crop production in India. J. Trace Elem. Med. Biol. 23:281-9.

Camberato J, Maloney S, 2012. Zinc deficiency in corn. Soil Fertility Update. Purdue University Department of Agronomy West Lafayette, USA. Available from: www.soilfertility.info/ZincDeficiencyCorn.pdf

Drissi S, Houssa AA, Bamouh A, Benbella M, 2015. Corn silage (Zea mays L.) response to zinc foliar spray concentration when grown on sandy soil. J. Agric. Sci. 7:68-79. 
Fageria N, Filho M, Moreira A, Guimarães C, 2009. Foliar fertilisation of crop plants. J. Plant Nutr. 32:1044-64.

Fernandez V, Brown PH, 2013. From plant surface to plant metabolism: the uncertain fate of foliar-applied nutrients. Front. Plant Sci. 4:93-106.

Furlani AMC, Furlani PR, Meda AR, Duarte AP, 2005. Efficiency of maize cultivars for zinc uptake and use. Sci. Agric. 62:26473.

Golden BR, Orlowski JM, Bond JA, 2016. Corn injury from foliar zinc application does not affect grain yield. Agron. J. 108:2071-5.

Grzebisz W, Wronska M, Diatta JB, Dullin, 2008a. Effect of zinc foliar application at an early stage of maize growth on patterns of nutrients and dry matter accumulation by the canopy. Part I. Zinc uptake patterns and its redistribution among maize organs. J. Elementol. 13:17-28.

Grzebisz W, Wrońska M, Diatta JB, Szczepaniak W, 2008b. Effect of zinc foliar application at early stage of maize growth on the patterns of nutrients and dry matter accumulation by the canopy. Part II. Nitrogen uptake and dry matter accumulation patterns. J. Elementol. 13:29-39.

Hacisalihoglu G, Kochian LV, 2003. How do some plants tolerate low levels of soil zinc? Mechanisms of zinc efficiency in crop plants. New Phytol. 159:341-50.

Hafeez B, Khanif YM, Saleem M, 2013. Role of zinc in plant nutrition - A review. Am. J. Exp. Agric. 3:374-91.

Haslett B, Reid R, Rengel Z, 2001. Zinc mobility in wheat: uptake and distribution of zinc applied to leaves or roots. Ann Bot (London) 87:379-86.

Imran M, Rehim A, 2017. Zinc fertilisation approaches for agronomic biofortification and estimated human bioavailability of zinc in maize grain. Arch. Agron. Soil. Sci. 63:106-16.

Imtiaz M, Alloway BJ, Shah KH, Siddiqui SH, Memon MY, Aslam M, Khan P, 2003. Zinc Nutrition of Wheat: II: Interaction of Zinc with other Trace Elements. Asian J. Plant Sci. 2:156-60.

Ivanov K, Kolentsova E, Nguyen N, Peltekov A, Angelova V, 2017. Synthesis and stability of zinc hydroxide nitrate nanoparticles. Bulg. Chem. Commun. 49:225-30.

Ivanov K, Tonev T, Nguyen N, Peltekov A, Mitkov A, 2019. Impact of foliar fertilisation with nanosized zinc hydroxy nitrate on maize yield and quality. Emir. J. Food Agric. 31:597604.

Jones Jr, Benton J, Wolf B, Mills HA, 1991. Plant analysis handbook. A practical sampling, preparation, analysis, and interpretation guide. Micro-Macro Publishing Inc., Athens, Georgia, USA.

Li P, Xu ZP, Hampton MA, Vu DT, Huang L, Rudolph V, Nguyen AV, 2012. Control preparation of zinc hydroxide nitrate nanocrystals and examination of the chemical and structural stability. J. Phys. Chem. C 116:10325-32.

Li P, Li L, Du Y, Hampton M, Nguyen A, Huang L, Xu Z, 2014. Potential foliar fertilisers with copper and zinc dual micronutrients in nanocrystal suspension. J. Nanopart. Res. 16:1-11.

Li P, Du Y, Huang L, Mitter N and Xu Z, 2016. Nanotechnology promotes the R\&D of new-generation micronutrient foliar fertilisers. RSC Adv 6:69465-78.

Liu H, Gan W, Rengel Z, Zhao P, 2016. Effects of zinc fertiliser rate and application method on photosynthetic characteristics and grain yield of summer maize. J. Soil Sci. Plant. Nutr. $16: 550-62$.
Liu DY, Zhang W, Liu YM, Chen XP, Zou CQ, 2020. Soil application of zinc fertiliser increases maize yield by enhancing the kernel number and kernel weight of inferior grains. Front. Plant Sci. 11:188-99.

Marschner P (Ed.), 2011. Marschner's mineral nutrition of higher plants. 3rd edn. Elsevier/Academic Press, Amsterdam, Netherlands, pp 222.

Mattiello E, Ruiz H, Neves J, Ventrell M, Araújo W, 2015. Zinc deficiency affects physiological and anatomical characteristics in maize leaves. J. Plant Physiol. 183:138-43.

Mills HA, 1996. Plant analysis handbook II. Micromacro Publishing, Athens, GA, USA.

Mohsin AU, Ahmad AUH, Farooq M, Ullah S, 2014. Influence of zinc application through seed treatment and foliar spray on growth, productivity and grain quality of hybrid maize. J. Anim. Plant. Sci. 24:1494-503.

Mousavi SR, 2011. Zinc in crop production and interaction with phosphorus. Aust. J. Basic Appl. Sci. 5:1503-9.

Moustakas NK, Akoumianaki AI, Barouchas PE, 2011. The effects of cadmium and zinc interactions on the concentration of cadmium and zinc in pot marigold (Calendula officinalis L.). Aust. J. Crop Sci. 5:277-82.

Papadopoulos F, Prochaska C, Papadopoulos A, Eskridg K, Kalavrouziotis I, 2009. Mn and Zn micronutrients concentrations in acidic soils and source identification using multivariate statistical methods. Commun. Soil. Sci. Plant. Anal. 40:235771.

Potarzycki J, 2010. Yield forming functions of zinc in maize crop review paper. Nawozy i Nawożenie 39:109-28.

Rehm GW, Sorensen RC, Wiese RA, 1983. Application of phosphorous, potassium and zinc to corn grown for grain or silage: nutrient concentration and uptake. Soil Sci. Soc. Am. J. 47:697-700.

Rengel Z, Graham RD, 1995. Importance of seed Zn content for wheat grown on $\mathrm{Zn}$ defiant soil vegetable growth. Plant. Soil. 176:217-24.

Rengel Z, Romheld V, Marschner H, 1998. Uptake of zinc and iron by wheat genocatypes differing in tolerance to zinc deficiency. J. Plant. Physiol. 142:433-8.

Sadeghzadeh B, 2013. A review of zinc nutrition and plant breeding. J. Soil Sci. Plant. Nut. 13:905-27.

Schreiber U, 2004. Pulse amplitude modulation (PAM) fuorometry and saturation pulse method: an overview. In: Papageorgiou GC (Ed.), Chlorophyll a fuorescence: a signature of photosynthesis. Kluwer Academic, Dordrecht, pp. 279-319.

Singh N, Amist N, Yadav K, Singh D, Pandey J, Singh S, 2013. Zinc oxide nanoparticles as fertiliser for the germination, growth and metabolism of vegetable crops. J. Nanoeng. Nanomanuf. 3:353-64.

Subbaiah LV, Prasad TNVKV, Krishna TG, Sudhakar P, Reddy BR, Pradeep T, 2016. Novel effects of nanoparticulate delivery of zinc on growth, productivity, and zinc biofortification in maize (Zea mays L.). J. Agric. Food Chem. 64:3778-88.

Tahir M, Fiaz N, Nadeem MA, Khalid F, Ali M, 2009. Effect of different chelated zinc sources on the growth and yield of maize (Zea mays L.). Soil. Environ. 28:179-83.

Wang H, Jin J, 2005. Photosynthetic rate, chlorophyll fluorescence parameters, and lipid peroxidation of maize leaves as affected by zinc deficiency. Photosynthetica 43:591-96. 